\title{
KORELASI KADAR KOLESTEROL TOTAL DAN LDL SERUM TIKUS HIPERKOLESTEROLEMIA SETELAH PEMBERIAN EKSTRAK DAUN SALAM (Eugenia polyantha)
}

\author{
Putu Oky Ari Tania'), I Kadek Putra Dwipayana ${ }^{2)}$, Kadek Adi Sudarmika ${ }^{3)}$ \\ ${ }^{1}$ Bagian Biomedik Penelitian Biomolekuler Fakultas Kedokteran \\ ${ }^{2,3}$ Fakultas Kedokteran \\ Universitas Wijaya Kusuma SurabayaDukuh Kupang XXV/ 54 Surabaya \\ Email:putu.oky@gmail.com
}

\begin{abstract}
ABSTRAK
Penggunaan herbal belakangan banyak ditemukan, terutama sebagai tanaman obat. Daun salam (Eugenia polyantha) adalah herbal yang banyak digunakan sebagai obat. Daun salam memiliki bahan aktif flavonoid, tannin dan vitamin B3 (niasin). Banyak penelitian menyatakan bahwa daun salam bermanfaat sebagai antikolesterol. Hiperkolesterol dapat terjadi dari asupan makanan tinggi lemak yang berkorelasi terhadap terjadinya aterosklerosis dan bermacam masalah kesehatan lainnya. Aterosklerosis sangat terkait dengan peningkatan kadar LDL. Tingginya kadar LDL sebagai faktor risiko aterosklerosis. oleh karena itu penelitian ini bertujuan untuk mengetahui korelasi antara kolesterol dan LDL pada tikus hiperkolesterol yang diobati dengan ekstrak daun salam. Desain penelitian ini adalah penelitian eksperimental dengan hewan coba ditikus jantan yang dibagi mejadi 4 kelompok yaitu KP, KN, P1, dan P2 semua tikus dikondisikan hiperkolesterolemia dengan pemberian diet tinggi lemak. P1 dan P2 adalah kelompok tkus hiperkolesterolemia yang diberikan ekstrak daun salam masing-masing dosis 0,72 dan 1,80 gram. Pada akhir perlakuan semua kelompok diterminasi dan diisolasi darahnya untuk dihitung kadar kolesterol total dan LDL pada tiap ekor tikus. Pada KP; KN; P1 dan P2 didapatkan rerata kadar kolesterol total adalah 37,$4 ; 36,6 ; 44,8$; dan 32,4 mg/dL, sedangka kadar LDL serum adalah 27,8; 23,8; 31,8 dan 25. Hasil uji statistik dengan korelasi Pearson menunjukkan signifikansi (2-tailed) sebesar 0,007 dan Pearson Correation sebesar 1. Dapat disimpulkan bahawa ada korelasi yang kuat antara kadar kolesterol total dan kadar LDL pada serum.
\end{abstract}

\section{Pendahuluan}

Daun salam (Eugenia polyantha) adalah herbal yang banyak digunakan sebagai obat. Daun salam memiliki bahan aktif flavonoid, tannin dan vitamin B3 (niasin) (Narita, 2015). Flavonoid adalah salah satu senyawa antioksidan yang dapat memerangi stres oksidatif. Faktor lingkungan seperti asupan makanan yang tinggi kandungan asam lemak jenuh merupakan penyebab ketidakseimbangan antara antioksidan dan pro-oksidan di jaringan. Konsumsi makanan tinggi lemak dapat menginduksi stres oksidatif (Zimmermann et al, 2013).

Asupan makanan tinggi lemak merupakan nutrisi yang dapat 
meningkatkan kolesterol di plasma darah, terutama pada individuindividu yang tidak mampu mempertahankan keseimbangan kolesterol di dalam tubuhnya (Barona and Fernandez, 2012). Pada kadar yang tepat, lemak memiliki fungsi penting di dalam tubuh. Peningkatan kadar lemak termasuk kolesterol dan trigliserida pada tubuh dikenal dengan hiperlipidemia (Rohilla et al, 2012).

Hiperlipidemia atau sering disebut juga dengan hiperkolesterol merupakan faktor risiko predominan untuk terjadinya aterosklerosis dan berkaitan dengan penyakit jantung koroner dan serebrovaskular (Palozza et al, 2012). Individu dengan hiperlipidemia atau aterosklerosis, livernya mengalami adaptasi yang rendah terhadap oksidatif atau berbagai jenis tekanan/ stress sehingga diduga mekanisme adaptif terhadap stress miokardial mengalami gangguan (onody et al, 2014).

Kolesterol dan komponen lemak lainnya tidak dapat larut dalam darah, oleh karena itu kolesterol diikat oleh molekul yang disebut lipoprotein, sehingga transportasi kolesterol antar sel dapat terjadi. Lemak dapat diklasifikasikan menjadi kolesterol total, trigiserida, kolesterol High Density Lipoprotein (HDL), Low Density Lipoprotein (LDL) dan Very Low Density Lipoprotein (VLDL) (Rohilla et al, 2012). Menurut WHO diprediksi tahun 2030, penyakit kardiovaskular akan menjadi penyebab kematian sekitar 23,6 juta manusia di Dunia, dan hiperkolesterolemia menyumbang 45\% serangan jantung di Eropa Barat. Risiko serangan jantung menjadi tiga kali lebih tinggi pada hiperkolesterolemia dibanding individu dengan profil lipid yang normal (Ooi and Liong, 2010). Aterosklerosis merupakan penyakit dengan pengerasan pembuluh arteri, akibat terbentuk plak di alamnya. Plak pada aterosklerosis mengandung LDL, makrofag, sel otot polos, platelet dan debris (Hao and Friedman, 2014).

Adanya berbagai masalah kesehatan akibat hiperkolesterolemia diperlukan terapi termasuk penggunaan obatobatan seperti Niasin, Fibrat, inhibitor HMG Co-A reduktase, dan lainnya, namun masih menimbulkan efek samping (Phogat et al, 2010). Untuk itu terapi herbal nampaknya merupakan salah satu solusi. Penelitian ini bertujuan untuk melihat hubungan atau korelasi antara kolesterol total dan LDL pada serum darah tikus hiperkolesterol dan setelah pengobatan yaitu dengan pemberian ekstrak daun salam.

\section{Metode Penelitian}

Penelitian ini merupakan penelitian dengan desain penelitian eksprimental kuantitatif dengan simple random sampling. 


\section{Induksi Hiperkoleserolemia}

Hewan coba pada penelitian ini menggunakan Tikus (Rattus norvegicus) jantan yang diagi menjadi 4 kelompok yaitu Kontrol positif (KP), Kontrol negatif (KN), Perlakuan 1 (P1), dan Perlakuan 2 (P2). Induksi hiperkolesteroemia pada semua kelompok dengan pemberian pakan tinggi lemak 20 gram/hari tiap ekor selama 12 hari. Pakan tinggi lemak yang diberikan mengandung lemak sebesar $26 \%$.

Setelah induksi hiperkolesterolemia, dilanjutkan dengan pemberian perlakuan pada masing-masing kelompok selama 7 hari. Kontrol Positif (KP) diberikan simvastatin dosis $0,0018 \mathrm{mg} /$ hari selama 7 hari. Kontrol Negatif (KN) diberikan aquades selama 7 hari. Kelompok Perlakuan 1 dan 2 (P1 dan P2) diberikan ekstrak daun salam masing-masing dosis $0,72 \mathrm{~g}$ dan $1,80 \mathrm{~g}$ secara oral.

\section{Ekstraksi Daun Salam}

Pembuatan ekstrak daun salam dilakukan metode maserasi pada etanol $70 \%$. Selanjutnya disaring dan filtrate diupakan dengan rotary evaporator sampai menjadi ekstrak kental.

\section{Pengukuran Kadar Koleterol Total dan LDL}

Pada akhir perlakuan, tikus diterminasi dan diambil darahnya secara intrakardiak. Darah dipisahkan dari serumnya untuk dilanjutkan dengan pengukuran kadar kolesterol total dan LDL menggunakan spektrofotometer (Rayto) dengan metode CHODPAP.

\section{Hasil Penelitian}

Pemberian pakan tinggi lemak dilakukan selama 12 hari dengan kadar lemak sebesar $26 \%$. Pemberian pakan tinggi lemak tersebut terbukti dapat meningkatkan kadark kolesterol total maupun LDL serum pada kelompok pra perlakuan yang dapat dilihat pada Tabel 1.

Tabel 1. Rerata Kadar Kolesterol dan LDL serum setelah pemberian pakan tinggi lemak

\begin{tabular}{ccc}
\hline Kelompok & \multicolumn{2}{c}{$\begin{array}{c}\text { Rerata kadar pada serum darah } \\
(\mathrm{mg} / \mathrm{dL})\end{array}$} \\
\hline & $\begin{array}{c}\text { Kolesterol } \\
\text { Total }\end{array}$ & LDL \\
\hline Pra Perlakuan & 64,4 & 57 \\
\hline
\end{tabular}

$\begin{array}{ccccccc}\text { Dapat } & \text { diamati, } & \text { kadar } & \text { pemberian } & \text { pakan tinggi lemak } \\ \text { kolesterol dan LDL } & \text { akibat } & \text { meningkat } & \text { hampir } & 2 & \text { kali lipat }\end{array}$ 
dibandingkan kelompok kontrol. sedangkan tertinggi pada P1 $(44,8$ Rerata kadar kolesterol maupun mg/dL). Untuk kadar LDL serum LDL serum pada tiap kelompok terendah ditunjukkan pada KN (238 dapat dilihat pada Tabel 2. Dari $\mathrm{mg} / \mathrm{dL}$ ) dan pada P1 menunjukkan tabel dapat digambarkan bahwa kadar LDL serum tertinggi $(31,8$ kadar kolesterol paling rendah $\mathrm{mg} / \mathrm{dL})$. terdapat pada P2 $(32,4 \mathrm{mg} / \mathrm{dL})$,

Tabel 2. Rerata Kadar Kolesterol dan LDL serum setelah pemberian perlakuan

\begin{tabular}{ccc}
\hline \multirow{2}{*}{ Kelompok } & \multicolumn{2}{c}{ Rerata kadar pada serum darah (mg/dL) } \\
\cline { 2 - 3 } & Kolesterol Total & LDL \\
\hline KP & 37,4 & 27,8 \\
KN & 36,6 & 23,8 \\
P1 & 44,8 & 31,8 \\
P2 & 32,4 & 25 \\
\hline
\end{tabular}

Perbandingan rerata kadar kenaikan dan penurunannya dapat Kolesterol total dan LDL serum dilihat pada Gambar 1. antara $\mathrm{KP}, \mathrm{KN}, \mathrm{P} 1$ dan $\mathrm{P} 2$ berikut

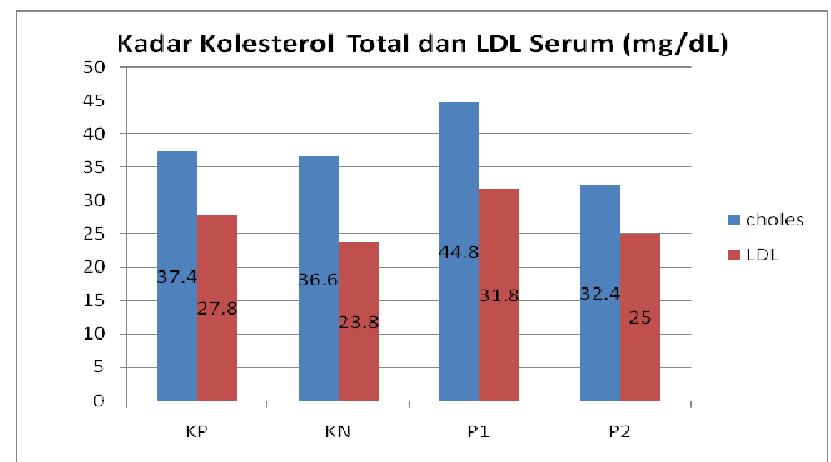

Gambar 1. Rerata Kadar Kolesterol dan LDL serum pada tiap kelompok

Gambar 1. menunjukkan bahwa peningkatan kadar kolesterol juga diikuti dengan penigkatan kadar LDL begitu pula penurunannya. Seperti pada kelompok P2 dbandingkan kelompok KP yang diberi simvastatin, terjadi penurunan baik pada kadar kolesterol total maupun LDL.

Untuk mengetahui korelasi antara kadar kolesterol total dan LDL serum, dilakukan dengan uji Spearman menggunakan SPSS 16.0. 
Output hasil korelasi atau hubungan antara keduanya dapat diamabti Tabel 3. Uji Korelasi Spearman antara Kadar Kolesterol Total dan LDL

\begin{tabular}{|ccrr|}
\hline & & Kolestero & LDL \\
& & 1 Total & \\
\hline Kolesterol & Pearson Corelation & 1,000 & $0,579^{*}$ \\
Total & Sig. (2-tailed) &. & 0,007 \\
& N & 20 & 20 \\
\hline LDL & Pearson Correlation & $0,570^{*}$ & 1,000 \\
& Sig. (2-tailed) & 0,007 & $\cdot$ \\
& N & 20 & 20 \\
\hline
\end{tabular}

*. Correlation is significant at the 0.05 level (2-tailed).

Uji korelasi Pearson menunjukkan bahwa signifikansi sebesar $0,007(<0,05)$ yang berarti ada korelasi antara kadar kolesterol total dan LDL di semua kelompok. Pearson Correlation menunjukkan nilai 1 yang berarti korelasi antara kadar kolesterol total dan LDL sangat kuat.

\section{Pembahasan}

Pemberian pakan tinggi lemak dengan kadar 26\% terbukti dapat meningkatkan kadar kolesterol diikuti dengan LDL. Hal ini dapat diamati pada kelompok praperlakuan, setelah pemberian pakan tinggi lemak selama 12 hari rerata kadar kolesterol menjadi 64,4 mg/dL dan kadar LDL sebesar 57 $\mathrm{mg} / \mathrm{dL}$. Pada tikus putih, kadar kolesterol normal berkisar antara 10-54 mg/dL (Harini dan Astirin, 2009). Tikus termasuk rodensia, umumnya mengonsumsi pakan rendah lemak yang mengandung hanya 4-6\% lemak (Getz and pada Tabel 3 . 
transportasikan sebagai trigliserida untuk menghindari toksisitasnya. Lipoprotein berperan dalam penyerapan dan transportasi lipid dari makanan melalui usus halus, transpor lipid dari liver ke jaringan perifer dan transport lipid dari jaringan perifer ke liver dan usus (transport kolesterol reverse). Trigliserida dalam makanan akan dihidrolisasi menjadi asam lemak dan monoasilgliserol oleh lipase usus dan asam empedu, kolesterol, sterol dari tanaman dan vitamin yang melarutkan lemak menjadi bentuk micelles. Sebagian besar kolesterol yang diserap oleh intestinal, diesterifikasi menjadi kolesterol ester, yang selanjutnya akan bergabung dengan trigliserida menjadi kilomikron di retikulum endoplasma. Jalur eksogenus lipoprotein menghasilkan transfer asam lemak berasal dari makanan, ke otot atau jaringan adipose untuk penggunaan energi atau simpanan lemak.

Kilomokron akan dikirimkan ke liver, di liver banyak ditemukan reseptor LDL. Konsentrasi reseptor LDL pada liver diatur oleh jumlah kolesterol pada sel. Trigiserida akan diangkut ke seluruh tubuh melalui VLDL. Trigliserida yang diangkut oleh VLDL akan dihidrolisis menjadi IDL di sirkulasi. Selanjutnya trigliserida di IDL juga mengalami hidrolisis melalui lipase hepatik, sehingga terjadi penurunan jumlah trigliserida dan terjadi pembentukan LDL (Feingold and Grunfeld, 2015). Pemberian diet tinggi lemak sebagai penyebab peningkatan biosintesis kolesterol terutama LDL.

Pada

keadaan

hiperkolesterolemia, pemberian simvastatin maupun aquades selama 7 hari, sangat mampu menurunkan kadar kolesterol total maupun LDL. Dapat diamati pada Tabel 2. Kadar Kolesterol total pada KP menjadi $37,4 \mathrm{~g} / \mathrm{dL}$, dan LDL $27,8 \mathrm{mg} / \mathrm{dL}$. Kadar kolesterol total Pada KN yang diberi aquades adalah $36,6 \mathrm{mg} / \mathrm{dL}$, sedangkan LDL $23,8 \mathrm{mg} / \mathrm{dL}$. Penurunan rerata kadar kolesterol total dan LDL pada KN justru nampak lebih besar dibanding KP. Dari hasil penelitian ditemukan bahwa hanya dengan aquades dapat menurunkan kadar kolesterol total dan LDL, aquades mampu membantu melancarkan proses metabolisme tubuh dan dapat pula menurunkan kadar kolesterol menurut Amirta (2007). Hasil serupa ditemukan pada Toxqui and Vaquero (2016), bahwa asupan air sangat esensial untuk pemeliharaan kesehatan, yaitu pemberian 1 liter air setiap hari elama 8 minggu dapat menurunkan kadar kolesterol LDL dan menurunkan indeks risiko kardiovaskuler.

Pemberian ekstrak daun salam dosis 1,80 gram per hari menunjukkan kadar kolesterol total yang paling rendah $(32,4 \mathrm{mg} / \mathrm{dL})$ dibandingkan tiga kelompok 
lainnya, yang diikuti menurunnya kadar LDL pula sebesar $25 \mathrm{mg} / \mathrm{dL}$. Daun salam telah banyak diteliti karena kandungan antioksidannya yaitu flavonoid, minyak atsiri, seskuiterpen, triterpenoid, fenol, dan vitamin A, E dan C (Siregar, 2015). Kandungan flavonoid dan tannin dapat menurunkan kolesterol yaitu menghambat HMG-CoA Reduktase dan menghambat absorpsi lemak di usus. Tingginya kolesterol pada makanan dapat menyebabkan stres oksidatif dan peroksidsi lipid yang ditunjukkan dengan tingginya kadar MDA (Lee et al, 2013). Sehingga aktivitas antioksidan sangat diperlukan pada kondisi hiperkolesterolemia ini.

Tujuan penelitian ini untuk melihat bagamana korelasi antara peningkatan atau penurunan kadar kolesterol total dan LDL. Uji korelasi Pearson menunjukkan sig. (2-tailed) sebesar 0,007 dengan korelasi sebesar 1,00. Ternyata koleterol total pada berbagai perlakuan sangat berkorelasi dengan kadar LDL. Lebih lanjut didapatkan korelasi yang positif, artinya semakin tinggi kadar kolesterol, maka akan meningkatkan kadar LDL (Tabel 3). Penelitian ini menunjukkan hasil yang serupa dengan penelitian pada pasien hemodialisa maupun keompok kontrol, LDL yang teroksidsi ditemukan memiliki korelasi yang positif denga kolesterol total ( $\mathrm{r}=$ 0,75) (Lee et al, 2013).
Seperti yang telah diketahui, kolesterol total dapat dipecah menjadi lipoprotein yang dapat diukur seperti HDL, LDL, IDL, VLDL, kilomikron remnan, dan trigliserida (Stapleton et al, 2010). Sehingga LDL merupakan parameter yang dapat diukur untuk melihat peningkatan kolesterol total di dalam tubuh. Peningkatan kolesterol total dan LDL sering dikaitkan dengan peningkatan risiko aterosklerosis dan penyakit jantung koroner. Beberapa agen atau obat anti hiperkolesterol seperti statin dapat menurunkan kadar LDL serta meningkatkan HDL. Untuk itu untuk memprediksi penyakit jantung koroner, American Heart Association menyarankan rasio total kolesterol/ HDL > 5 yang mengindikasikan risiko tinggi terhadap penyakit jantung (Hao and Friedman, 2014).

\section{Kesimpulan}

Terdapat korelasi yang kuat antara kolesterol total dan LDL serum pada tikus hiperkolesterolemia setelah pemberian ekstrak daun salam dengan sig. (2-tailed) sebesar 0,007 dan koreasi yang positif dengan besar 1,00.

\section{Saran}

Dilakukan penelitian serupa dengan melihat prediksi penyakit jantung dengan korelasi kolesterol total/ kadar HDL. 


\section{Ucapan Terimakasih}

Terimakasih kepada semua pihak yang membantu terlaksananya penelitian ini terutama I Kadek Putra Dwipayana, Kadek Adi Sudarmika dan I Kadek Angga Dwi Cahyadi.

\section{Daftar Pustaka}

Amirta, Y. 2007. Sehat Murah dengan Air. Purwokerto Utara : Keluarga Dokter.

Barona, J. and M.L. Fernandez. 2012. Dietary Cholesterol Affects Plasma Lipid Levels, the Intravascular Processing of Lipoproteins and Reverse Cholesterol Transport without Increasing the Risk for Heart Disease. Nutrients, 4, 1015-1025.

Feingold, K.R. and C. Grunfeld. 2015. Introduction to Lipids and Lipoproteins. NCBI. Endotext bookshelf

Getz, G.S. and C.A. Reardon. 2006. Diet and Murine Atherosclerosis. Atherioscler Thromb Vasc Biol, 26, 242249

Hao, W. and A. Friedman. 2014. The LDL-HDL Profile Determines the Risk of Atherosclerosis: A Mathematical Model. Plos One, 9(3), 1-15

Harini, M. dan O.P. Astirin. 2009. Kadar Kolesterol Darah
Tikus Putih (Ratts noervegicus)

Hiperkolesterolemik Setelah Perlakuan VCO. Nusantara Bioscience, 1, 53-58

Kaprinay, B, B. Liptak, L. Slovak, k. Svik, V. Knezl, R. Sotnikova and Z. Gasparova. 2016. Hypertriglyceridemic Rats Fed High Fat Diets as Model of Metabolic Syndrome. Physiol. Res. 65 (suppl. 4), s515-s518

Lee, Young-Ki, D.H. Lee, J.K. Kim, Min-Jeong Park, Ji-Jing Yan, Dong-Keun Song, N.D. Vaziri and Jung-Woo Noh. 2013.

Lysophosphatidylchoine,

Oxidized Low-Density Lipoprotein and Cardiovascular Disease in Korean Hemodialysis Patients: Analysis at 5 Years of Follow-up. JKMS, 28, 268-273

Lee, Lan-Sook, Chang-Won Cho, Hee-Do Hong, Young-Chul Lee, Ung-Kyu Choi, and Young-Chan Kim. 2013. Hypolipidemic and Antioxidant Properties of Phenolic Compound-Rich Extracts from White Ginseng (Panax ginseng) in Cholesterol-Fed Rabbits. Molecules, 18, 12548-12560 Narita, E.A.R. 2015. Bay Leaf in Dyslipidemia Therapy. J Majority, 4(4), 64-69 
Onody A., C. Csonka, Z. Giricz, and P. Ferdinandy. 2014. Hyperlipidemia Induced by a Cholesterol-Rich Diet Leads to Enhanced Peroxynitrite Formation in Rat Hearts. Cardiovascular Research, 58, 663-670

Ooi, Lay-Gaik and Min-Tze Liong. 2010. Cholesterol-Lowering effects of Probiotics and Prebiotics: A Review of in Vivo and in Vitro Findings. Int. J. Mol. Sci, 11, 24992522

Palozza, P., A. Catalano, R.E. Simone, M.C. Mele, A. Cittadini. 2012, Effect of Lycopene and Tomato Products on Cholesterol Metabolism. Ann Nutr Metab, 61, 126-134

Phogat P., A. Deep., P.C. Sharma, S.K. Mittal, S. Kakkar, R. Goyal, K. Thakral. 2010. Introduction to Hyperlipidemia and Its Management: A Review. Pharmacologyonline, 2, 251266

Rohilla, A., N. Dagar, S. rohilla, A. Dahiya, and A. Kushnoor. 2012. Hyperlipidemia-A Deadly Pathological Condition. International
Journal of Current

Pharmaceutical Research, 4(3), 15-18

Siregar, R.N.I. 2015. The Effect of Eugenia polyantha Extract on LDL Cholesterol. J Majority, 4(5), 85-92

Stapleton, P.A., A. G. Goodwill, M.E. James, R.W. Brock, and J.C. Frisbee. 2010. Hypercholesterolemia and Microvascular Dysfunction: Interventional Strategies. Journal of Inflammation, 7: 54

Toxqui, L. and M.P. Vaquero. 2016. An Intervention with Mneral Water Decreases Cardiometabolic Risk Biomarkers. A Crossover, Randomized, Controlled Trial with Two Mineral Waters in Moderately Hypercholesterolaemic Adults. Nutrients, 8(400), 112

Zimmermann, A.M., A.C. Rivero, A.S. Bezerra, A.R. Ruviaro, M.M.E. Novack and J.L. Nornberg. 2013. Antioxidant Potential of Barley Extract in Rats Subjected to a High-Fat Diet. Food Science and Technology, 33(1), 167-171. 